\title{
フッ素ポリマーを分散安定剤とする 非水ポリマーディスパージョン
}

奴間 伸 茂*

\section{1. は じめに}

溶剤可溶型フッ素ポリマーを分散安定剂として 用い, サブミクロンオーダーのアクリルポリマー 微粒子を有機溶剂中に安定に分散させた非水ポリ マーディスパージョン1 8)の特徵と応用について 述べる.

非水ポリマーディスパージョン(Non-Aqueous Polymer Dispersion : 以下 NAD と略記する)に関 してはBarret 等の成書9)をはじめ多くの文 献 ${ }^{10 \sim 11)}$, 特許 ${ }^{12 \sim 19)}$ が提出されている. すでに自 動車上塗りメタリック塗料の分野では, アルミ顔 料の配向コントロール，クリヤー塗料のたれ落ち 抵抗性の付与, 耐候性向上を目的として，主とし てアクリルポリマーを分散安定剤とするNADが 多量に使用されている20). 常温乾燥塗料分野で は, 酸化硬化型アルキドポリマーを分散安定剂と する NAD が開発され, 塗膜の乾燥性, 機械的性 質の向上, 塗り重ね時の縮み現象防止に効果のあ ることが報告されている21).

溶剤可溶型フッ素ポリマーについては, 山辺, 小島, 宗像らから文献22 24), 特許 ${ }^{25)}$ が提出され ている。これは，旭硝子(侏により開発され昭和 58 年に商品化された，フルオロエチレン/ビニルエ 一テル共重合体 (Fluoroethylene/vinyl ether copolymer: 以下 FEVE と略記する)である。水酸 基をもつ FEVEをポリイソシアナート，メラミ ン・ホルムアルデヒド樹脂等の架橋剤で硬化させ た塗膜は, 従来のアクリルポリオール硬化塗膜に 比べ，耐候性，耐酸性に優れていることが確認さ れている。

またFEVE以外にも各社で溶剤可溶型フッ素 ポリマーが開発されており 26 29) いずれも耐候性
に優れている点を特徴としている.

今回, FEVEを分散安定剤とする NAD(以下 FEVERAD と略記する：FEVE Reinforced with Acrylic Dispersion)を開発・商品化した背景には 塗料に要求される性能の絶えざる高度化, 多様化 がある．例えば高耐候性だけではなく鏡面仕上げ のような高級感あふれる外観を与える塗料, 最近 問題視されるよらになった酸性雨におかされず, かつ，人手不足の世情を反映して熟練塗装技能者 でなくとも高品位な仕上りが得られる塗料に対す るニーズ等が挙げられる。もちろん，このような 要求を満たすために塗膜の機械的特性をはじめと する他の諸性能を犠牲にすることは許されない。

このような達成困難な課題をポリマーの面から 克服していくには従来用いられているポリマーの 改良, 複合化だけでは限界がある. 従来型ポリマ 一の限界を超えた新規ポリマーの開発, 利用が不 可欠となってくる.

このよらな状況のもと筆者らは従来型ポリマー の耐候性, 耐酸性等の耐化学薬品性の限界を超え るポリマーとして FEVEに着目し，更に機械的 特性, レオロジー的特性等の制御をできる限り自 由に行えるよら従来型ポリマーとしてアクリルポ

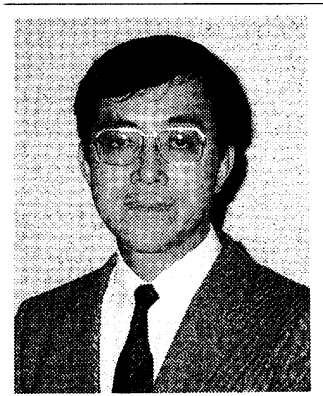

* 関西ペイント株式会社技術

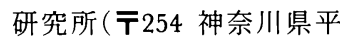
塚市東八幡 4-17-1) 第 1 部 課長. 昭和 47 年, 東京大学 理学部化学科卒業. 48年, 関西ペイント株式会社入 社, アクリルポリマー, 各 種複合系ポリマーの開発に 従事.〈趣味〉ウォーキン グ, ゴルフ 
表 1 FEVERAD の合成に使用した FEVE の例

\begin{tabular}{|c|c|c|c|c|c|c|}
\hline グレード & $\begin{array}{c}\text { フッ素含有量 } \\
\text { (WT.\%) }\end{array}$ & $\begin{array}{c}\text { 水酸基価 } \\
\mathrm{mgKOH} / \mathrm{g} \text {-ポリマー }\end{array}$ & $\begin{array}{c}\text { 酸 } \\
\mathrm{mgKOH} / \mathrm{g} \text { 価 } \\
\mathrm{m} \text { ポマー }\end{array}$ & \multicolumn{2}{|c|}{$\begin{array}{c}\text { 平均分子量* } \\
\text { MN MW }\end{array}$} & $\begin{array}{c}\text { ガラス転移点 } \\
\left({ }^{\circ} \mathrm{C}\right)\end{array}$ \\
\hline$\# 200$ & 27 & 52 & 0 & 19000 & 49000 & 38 \\
\hline$\# 400$ & 27 & 47 & 5 & 21000 & 95000 & 38 \\
\hline$\# 4006$ & 27 & 100 & 5 & 11000 & 29000 & 38 \\
\hline
\end{tabular}

* GPC 測定による

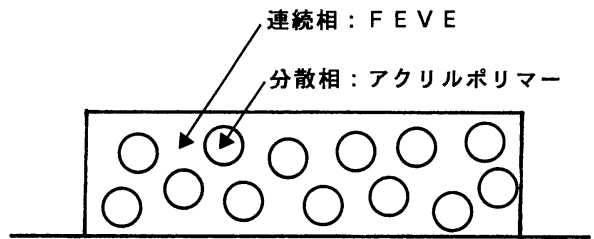

図 1 FEVE/アクリルポリマー複合塗膜概念図

リマーを選び両者の複合化を目指した。

複合化にあたり，塗膜のミクロ構造が図 1 の概 念図のよらな姿になることを目指した，基本的な 考え方を以下にまとめる.

(1) FEVEの最大の特徵である, 耐候性・耐化学 薬品性等を損ならことなく最大限発揮させるた め塗膜の連続相 (海相)はFEVEとする。必然 的に表面層も FEVEとなる。

(2) アクリルポリマーには，機械的特性を補強 し，かつレオロジー特性をより広い範囲で制御 可能とする役割をもたせることにしたが，上記 (1)を実現するためアクリルポリマーを分散相 (島相)とする. 分散相であるアクリルポリマー の機械的特性 ${ }^{20), 30)}$, レオロ ジー的特性 ${ }^{11)}$ に及 ぼす効果については従来の NAD の知見から充 分期待できる.

(3) 塗料の貯蔵安定性, 塗面の高仕上り性, クリ ヤーフィルムの透明性の観点から, 安定な不均 一系であり，かつ粒径の制御が自在にできるこ とが必須である。そこで，これらの条件を満た す最適の手法としてNADの合成手法を用いる こととする.

これにより分散相を形成するアクリルポリマ 一を高分子量あるいは架橋構造をもつものとし てもディスパージョンの粘度を高めることなく 塗料のハイソリッド化にも有利となる ${ }^{11)}$.

以上の考方方に基づいて開発，実用化すること ができた FEVERADについて以下述べる。

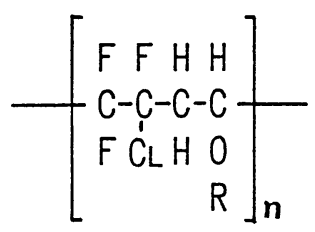

図 2 FEVE の化学構造式概念図

$\mathrm{R}$ :アルキル基, シクロアルキル基, ヒドロ キシアルキル基, カルボキシアルキル基

表 2 FEVERAD 合成配合例

\begin{tabular}{lcc}
\hline \multicolumn{1}{c}{ 原 材 料 } & 重量部 & \\
\hline FEVE\#400 $(60 \%)$ & 108 & \\
酢酸エチル & 8 & $\mathrm{I}$ \\
ヘプタン & 102 & \\
\hline アクリルモノマー混合物 & 100 & $\mathrm{II}$ \\
重合開始剂 & 1.5 & \\
\hline 酢酸エチル & 11 & $\mathrm{III}$ \\
重合開始剂 & 0.15 & \\
\hline
\end{tabular}

分散安定剂/分散粒子ポリマー(アクリルポリマー)

$: 40 / 60$ 固型分重量比

分散安定剤の SP : 8.80

アクリルポリマーの SP : 9.84

分散媒の SP : 8.10

平均粒子径 : 0.8 micrometer

\section{FEVERAD の合成}

\section{1 合成の概要}

表 1 に今回FEVERADの合成に使用した FEVE(旭硝子(侏製)の代表例を，図 2 に FEVEの 構造式を示す。

表 2 には FEVERAD の合成配合例を示す，反 応容器に I を仕込み, 一定温度まで昇温後, II を 一定時間で供給, 残存モノマーをIIIで重合させ る。詳細は特許5) にゆずるが，分散安定剂ポリマ 一，粒子を形成するアクリルポリマー，分散媒の 


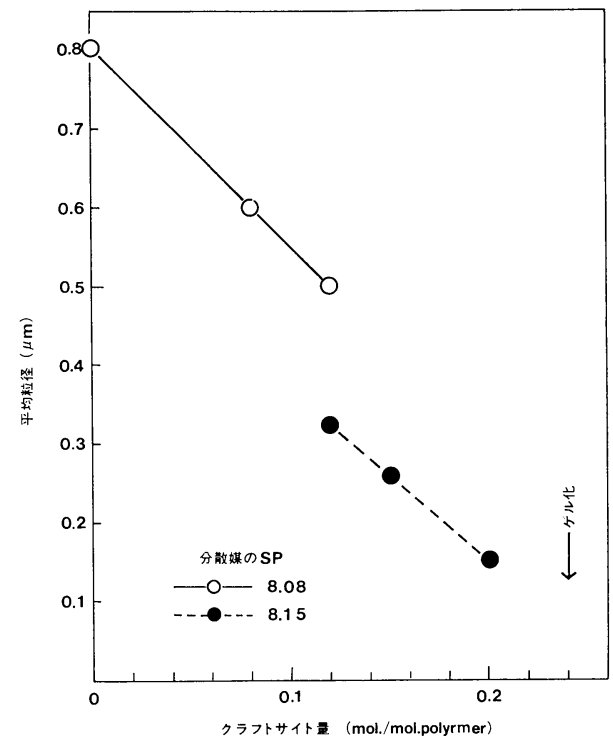

図 3 FEVEのグラフトサイト量と FEVERADの 平均粒子径(動的光散乱法に基づくコールタ ーN4(コールター社製)により測定)

溶解性パラメーター $(\mathrm{SP})$ の設定が重要となる. 表 2 の例においては, 反応温度 $\left(80 \sim 90^{\circ} \mathrm{C}\right)$ で $\mathrm{SP}=8.80$ の分散安定剤は, $\mathrm{SP}=8.10$ の分散媒に 溶解する。アリリルモノマー(及び重合開始剤) は, この分散媒に溶解するが，これらモノマーが 重合した SP=9.84のアクリルポリマーは溶解し ない。

\section{2 粒子径の制御}

表 2 の例では, 分散安定剤ポリマーと分散アク リルポリマー粒子とは物理的親和力により結合し ている，粒子径は分散安定剤ポリマーの割合を増 加させることにより，更に小さなものとすること が可能である. しかしながら, 粒径制御に最も有 効な手段は, 分散安定剤ポリマーとアクリルポリ マーとのグラフト化の程度の調整である.

図 3 に表 2 の例の FEVE に導入した重合性二 重結合量と, 得られた FEVERADの平均粒子径 の関係を示した.グラフトサイトの増加とともに 平均粒子径は小さくなっていくことがわかる.た だし図 3 の例では, 重合性二重結合量が 0.2 mol./mol. polymer を超えると FEVERAD の粘度 は上昇し，やがてゲル化にいたる。これは， FEVE 1 分子中に複数の重合性二重結合が入る確 率が高くなるためである.
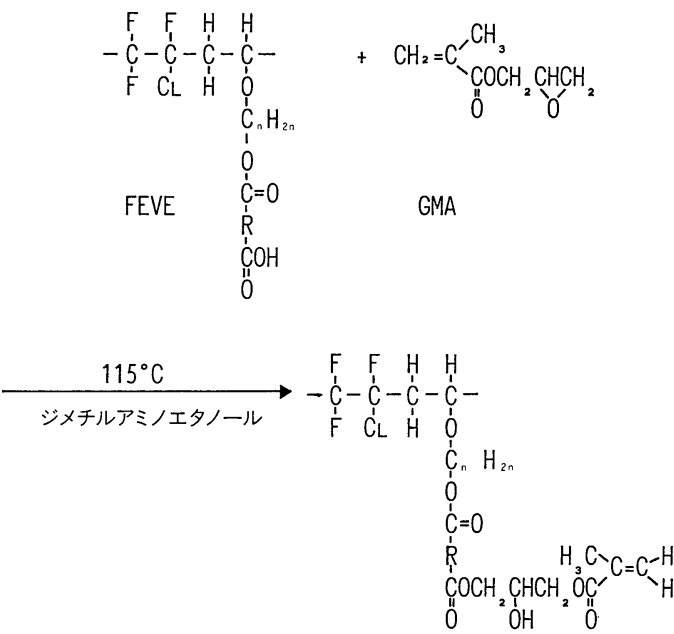

$$
R:-C_{n} H_{2 n} \text {, }
$$

図 4 FEVE の重合性二重結合の導入

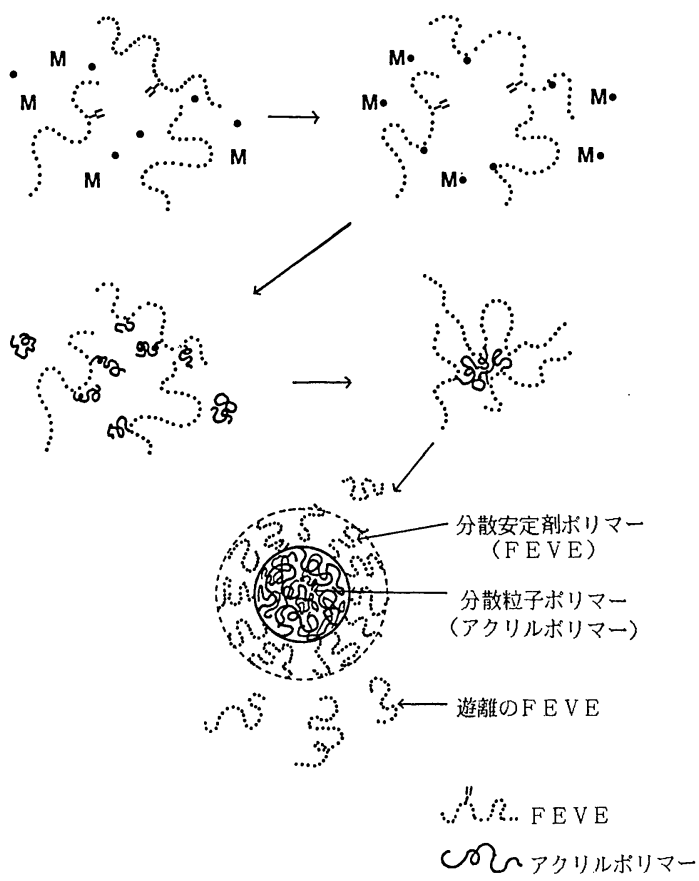

図 5 FEVERAD 生成概念図

重合性二重結合の導入法は種々の方法がある が，図4にその一例を示す。

なお，図 3 から分散媒の SP と平均粒子径の関 
係もわかる. 重合性二重結合量 $0.12 \mathrm{~mol} . / \mathrm{mol}$. polymer の点で, $\mathrm{SP}=8.15$ の分散媒を用いた方が, $\mathrm{SP}=8.08$ の分散媒を用いたものより小さな平均 粒子径のものが得られる。これは $\mathrm{SP}=8.15$ の分 散媒中において FEVEが分散安定剤ポリマーと してより有効に働くためである。すなわち， FEVEがより良く溶解され，より厚い立体反発層 を形成するためである．SPが 8 以下になると FEVE 自体が充分に溶解しないため, 立体反発層 が薄くなり粗大粒子の発生が見られるよらにな る。逆に SPが 9 以上になるとアクリルポリマー の膨潤が起こり, FEVERAD の増粘, プリン化 につながる。

図 5 に FEVERAD 生成の概念図を揭げる。

\section{FEVERAD の特性}

\subsection{FEVERAD のミクロ構造}

図 6 にディスパージョン状態の粒径分布( コー ルターN4にて測定)及びポリイソシアナート架 橋剤で硬化させたフィルムの透過型電顕(TEM) 写真を示す。比較に揭げた従来型のアクリルポリ マーを分散安定剤とする NAD に比べ，粒径分布 がより狭いことがわかる。

図 7 には小粒径タイプ (平均粒子径 $0.05 \mu \mathrm{m}$ 級) の FEVERADの硬化フィルムの TEM 写真を示 す. 比較のアクリルポリマーを分散安定剤とする NADは，同一条件で合成されたものであり，分 散安定剂ポリマーの SP，平均分子量等は同程度

\section{F E V E R A D}
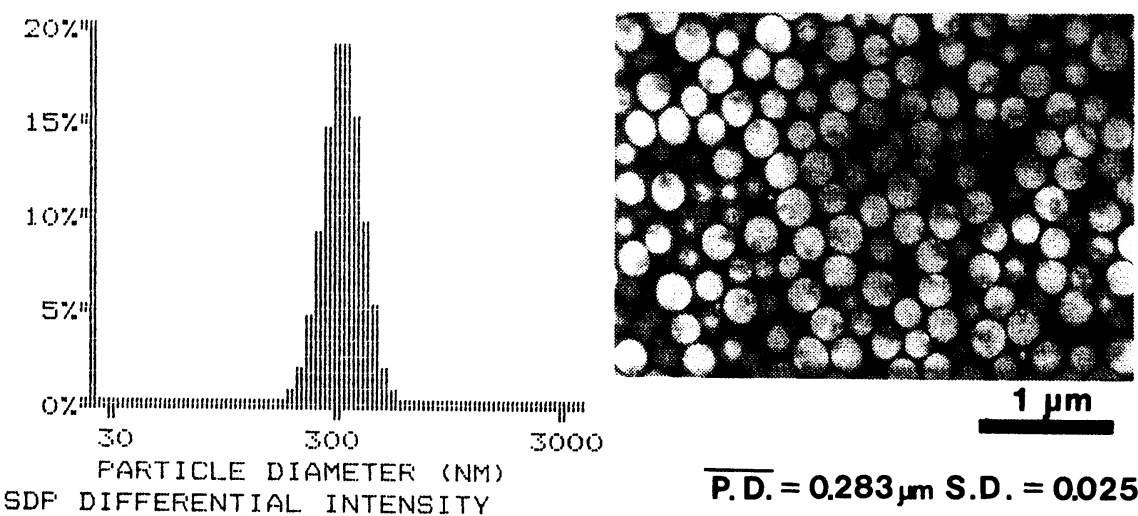

SDF' DIFFEFIENTIAL INTENSITY

$$
\overline{\text { P.D. }}=0.283 \mu \mathrm{m} \text { S.D. }=0.025 \mu \mathrm{m}
$$

アクリルポリマーを分散安定剤とする NAD

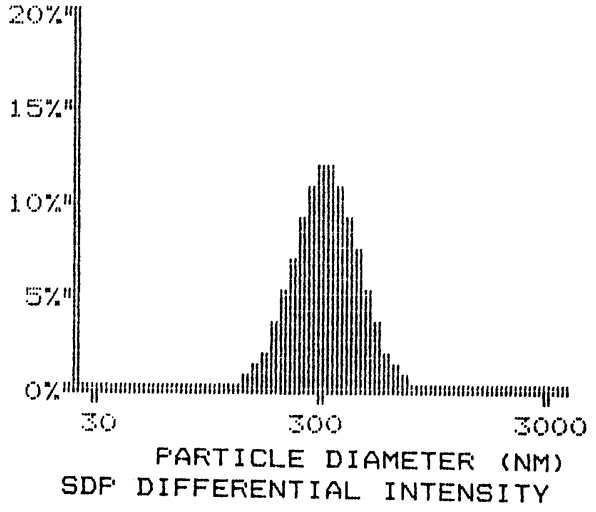

ディスパージョンの粒径分布*

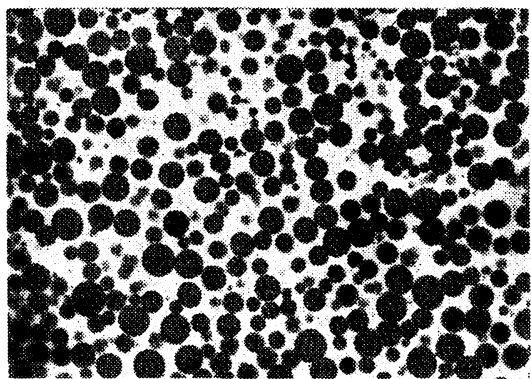

$1 \mu \mathrm{m}$

$$
\overline{\text { P.D. }}=0.295 \mu \mathrm{m} \text { S.D. }=0.092 \mu \mathrm{m}
$$

フィルムの TEM 写真

図 6 FEVERAD とアクリルポリマーを分散安定剤とするNADのミクロ構造の比較 *:コールターN4による 

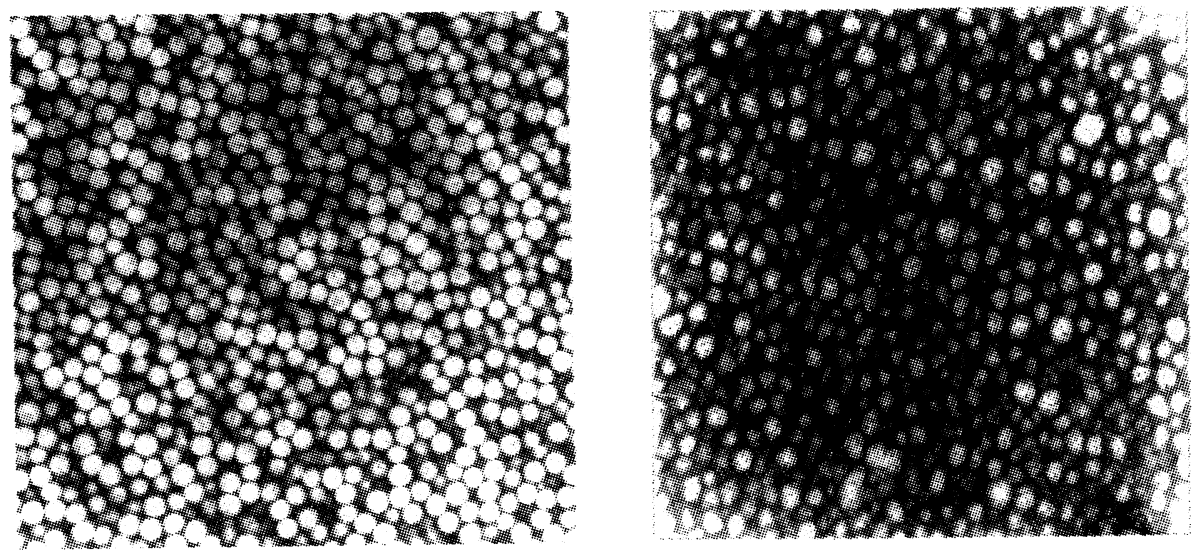

TEM

FEVERAD

\section{Acrylic NAD}

図 7 小粒径タイプ NAD の TEM 写真

一アクリルポリマーを分散安定剤とするNAD との比較

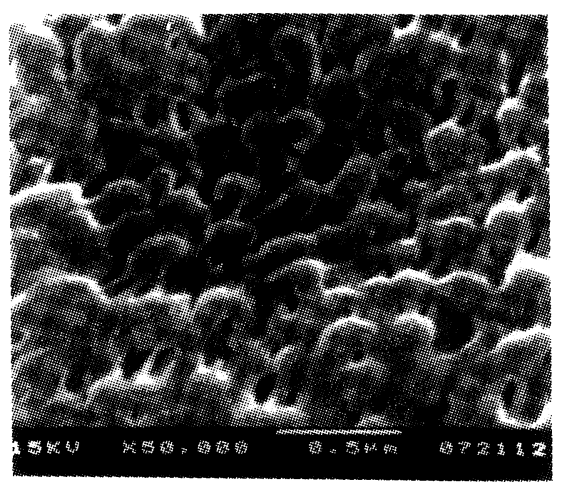

図 8 FEVERAD の凍結状態の SEM 写真

に設定したものであるＦEVERADの粒子のほ らが真球に近いものであることがわかる.

この点に関しては, 静的光散乱測定の結果得ら れた慣性自乗半径の比較から，FEVEのほらが同 程度の $\mathrm{SP}$, 平均分子量, $T_{\mathrm{g}}$ 点を持つアクリルポ リマーに比べ，ょり厚い立体反発層を持つこと， 更に FEVEとアクリルポリマーの表面エネルギ 一の差(図10)から FEVEのほうが分散安定剤と してはより有効に働くためと推察している.

図 8 には FEVERAD の凍結状態の SEM 写真 を, 図 9 には, FEVERADをポリイソシアナー 卜架橋剂で硬化させて得られたフィルムの破断面 のSEM 写真を示す.ディスパージョン状態にお

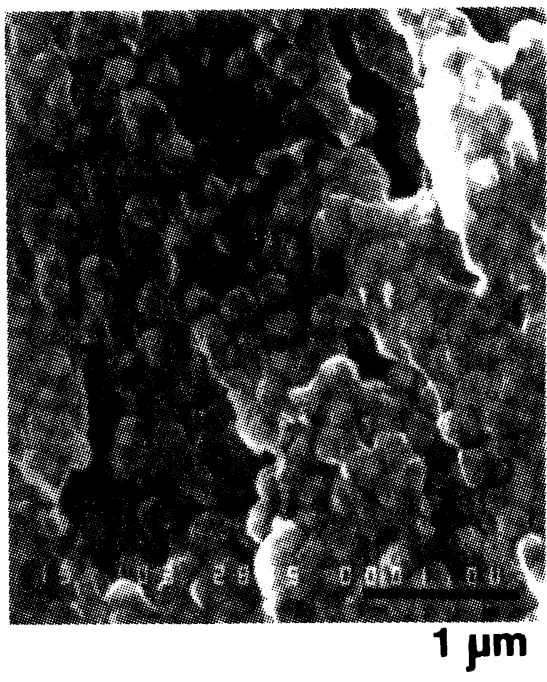

図 9 FEVERAD 硬化フィルム破断面の SEM 写真

ける分散粒子が硬化フィルムにおいてもそのまま 粒子状になっているのがよくわかる.TEM 写真 では, 試料フィルムの超薄切片一本報の TEM 写 真の場合 $400 \AA(0.04 \mu \mathrm{m})$ 程度一を観察するため, 分散粒子のどの部分が切断されているか実際には わからない（それでも図6では FEVERAD 硬化 フィルム中の粒径はそろっているように見える が)一方, 硬化フィルムの破断面の SEM 写真で 


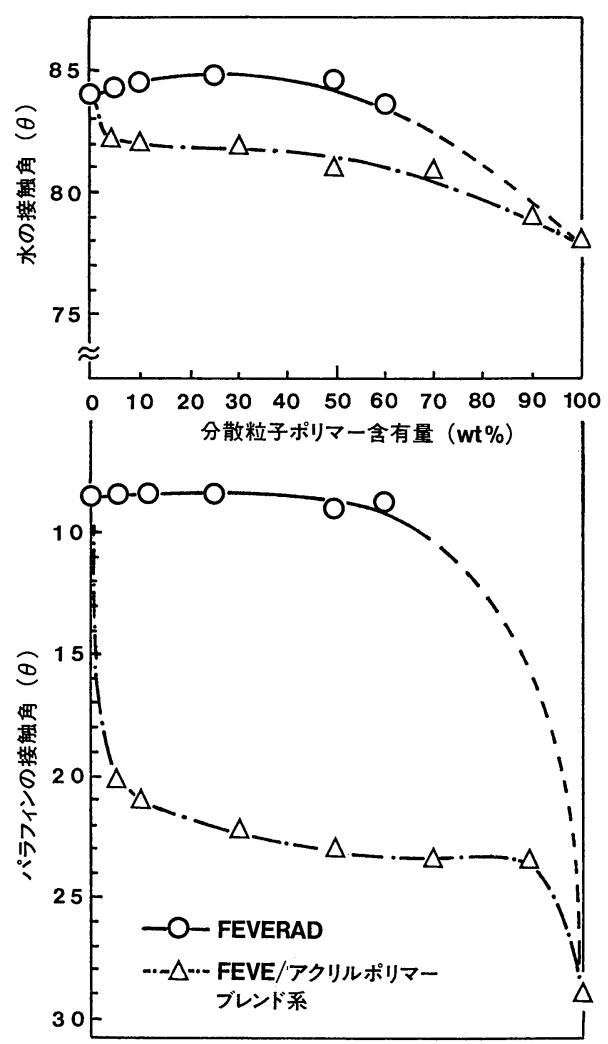

図10 FEVERAD 塗膜と FEVE/アクリルポリマー ブレンド塗膜上の水, パラフィン接触角の 比較

FEVERAD : 分散安定剤; FEVE\#200分散 安定剤/分散粒子ポリマー $=40 / 60,50 / 50$, $75 / 25$ (固型分重量比), 分散粒子ポリマーの ガラス転移点 $=52^{\circ} \mathrm{C}$

アクリルポリマー：水酸基価 $=82$, ガラス 転移点 $=63^{\circ} \mathrm{C}$, 重量平均分子量 $=16000$

は各粒子の全体像が観察できる。図 9 からも FEVERAD の分散粒子径はよくそろっているこ とが直観できる.

なお，FEVERAD 硬化フィルムのモルホロジ 一に関しては, 静的光散乱による解析も行ってい る. 分散相を真球と仮定したデバイプロットによ る解析の結果得られた平均粒径は TEM 写真から 得られた平均粒径と非常に良く一致していること がわかっている31).

\subsection{FEVERAD 塗膜の表面の性質}

図10に，FEVERAD より得られた乾燥塗膜と， FEVE/アクリルポリマーブレンド系より得られ
表 3 FEVERAD, FEVE 硬化フィルム*の帯電特性

\begin{tabular}{l|cccc}
\hline & \multicolumn{2}{|c}{ FEVERAD } & \multicolumn{2}{c}{ FEVE } \\
\hline 電荷の正負 & + & - & + & - \\
帯電量 $(\mathrm{KV})$ & 1.10 & 1.55 & 1.75 & 2.25 \\
半減期 $(\mathrm{min})$ & 1.1 & 1.5 & 85 & 80 \\
\hline
\end{tabular}

相対湿度 : $60 \%$. 温度 : $20^{\circ} \mathrm{C}$

印加電圧 : $8.0 \mathrm{KV}(5 \mathrm{~min})$

プローブと試験の距離 : $20.0 \mathrm{~mm}$

*ポリイソシアナート架橋剤により硬化したフィル ム

FEVERAD : 分散安定剂 : FEVE\#200,分散安定剂/ア クリルポリマー $=40 / 60$ (固型分重量比)

FEVE : \#200/\#400 = 80/20 (固型分重量比)

た乾燥塗膜上の水及び流動パラフィンの接触角を 観察した結果を示す．横軸はFEVERADの場合 は分散アクリルポリマー粒子の含有量であり，ブ レンド系の場合はアクリルポリマーの含有量であ る.

FEVERAD より得られた塗膜の接触角は，い ずれの場合も，分散安定剤として用いた FEVE 乾燥塗膜の接触角と同様の值を示した。一方，ブ レンド系では, FEVE 単独塗膜とアクリルポリマ 一単独塗膜の接触角の中間の值を示した.

このことから FEVERADの連続相，したがっ て, 乾燥塗膜の表面層は, 設計当初に意図したよ うに FEVEからなることがわかる。

この点に関しては, FEVERADを超遠心分離 機にかけて (50000回転 $\times 1$ 時間) 得られた上澄液 の IR 分析からも裏付けられている31).

\subsection{FEVERAD フィルムの帯電特性}

表 3 に, フィルムに $8.0 \mathrm{kV}$ の高電圧を印加し た場合の帯電圧と, その半減期について測定結果 を示した。測定は図11に示す帯電電荷減衰度測定 器スタティックオネストメーター(シシド静電気 (侏製)を用いた。測定雾囲気は， $20^{\circ} \mathrm{C}$ ，相対湿度 $60 \%$ 。印加プローブと試料フィルムの間隔は20 $\mathrm{mm}$, 印加時間は 5 分間であった.

FEVERADから得られた硬化フィルムは，分 散安定剤に用いた FEVEから得られた硬化フィ ルムに比べ，帯電しにくく，乙かも半減期が非常 に短いことがわかる。アクリルポリマーから得ら れる硬化フィルムはFEVEと同様の傾向をとる ことから, FEVERAD 硬化塗膜特有のミク口構 造に起因するものと推察している. 


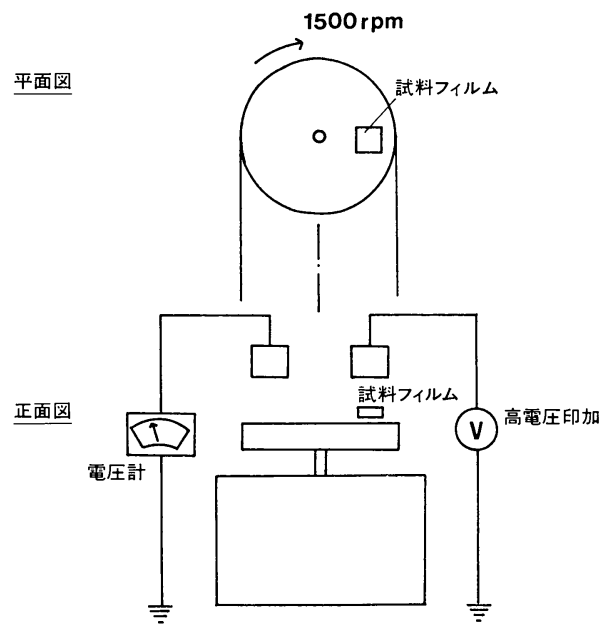

図11 エレクトロスタティックオネストメーター概 念図(ターンテーブル式)

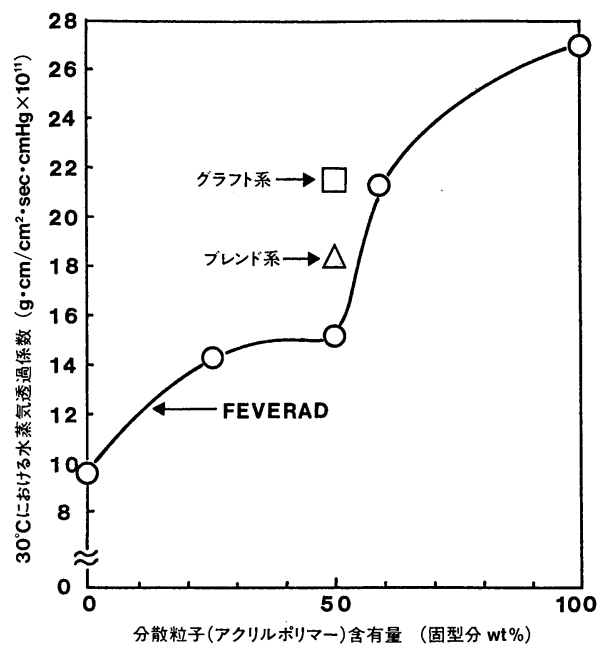

TEM
写 真

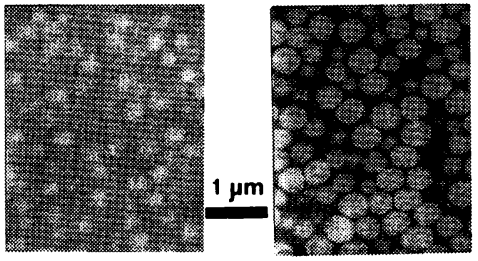

D.P. $=25$ WT.\%

$D . P .=60 W T . \%$

図12 FEVERAD 硬化フィルムの水蒸気透過係数 *ポリイソシアナート架橋剤により硬化

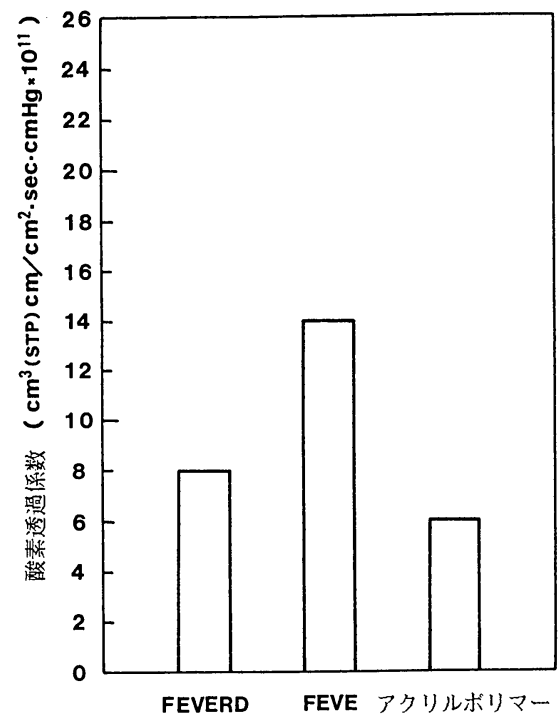

図13酸素透過係数比較

試料：ポリイソシアナート架橋剤による硬化 フィルム

FEVERAD：分散安定剂; FEVE \#200分散 安定剂/分散粒子ポリマー $=40 / 60$ (固型分重 量比), 分散粒子ポリマーガラス転移点 $=52^{\circ} \mathrm{C}$ FEVE: \#200/ \#400=80/20 (固型分重量比) アクリルポリマー：水酸基価 $=82$, ガラス転 移点 $=63^{\circ} \mathrm{C}$, 重量平均分子量 $=16000$

\subsection{FEVERAD フィルムのガス透過性}

図12に FEVERAD 硬化フィルムの水蒸気透過 係数が，アクリルポリマー粒子分の増加とともに 大きくなっていく様子を示した。 アクリルポリマ 一粒子分 $50 \mathrm{wt} . \%$ 程度迄は，緩やかに上昇してい くが， $60 \mathrm{wt} . \%$ 程度から急激に上昇する。これは， TEM 写真からもわかるように, 比較的透過係数 の大きいアクリルポリマー粒子が，かなり接近し てくるためと考えられる.

アクリルポリマー粒子分50 wt.\%のところで, 同一アクリル含有量の, FEVE/アクリルポリマ ーブレンド系，グラフト系と比較すると FEVERAD 硬化塗膜のほらが水蒸気透過係数は よりFEVEに近いことがわかる。これは FEVERADの連続相が FEVE よりなることに起 因する.

図13では，FEVERAD 硬化フィルムの酸素透 過係数を FEVE，アクリルポリマーおのおのの硬 化フィルムと比べた結果を示す．FEVERADは 他 2 者の中間の値を示している. 


\section{FEVERAD の応用}

\section{1 機械的特性の補強}

一般に硬く, 伸び率の小さいもろい硬化塗膜を 与える系にNADを配合することにより，伸び 率，剛性率ともに増加させることができ，一方破 断抗張力が小さく柔らかい，ひ弱な塗膜を与える 系に NAD を配合すると, 破断抗張力, 伸び率, 剛性率ともに増大して, 強靭な塗膜に改良される ことが報告されている20),32),33).

図14で，FEVERADから得られた硬化塗膜の

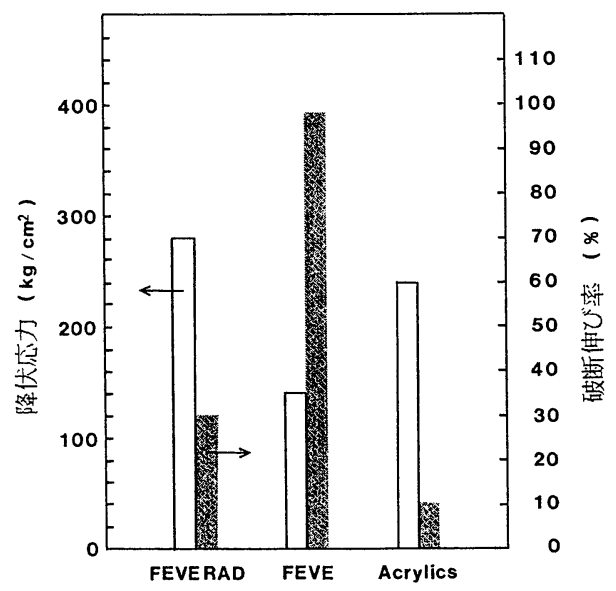

図14 硬化塗膜の引張り特性比較

試料：ポリイソシアナート架橋剤による硬化 フィルム(図13に同じ)

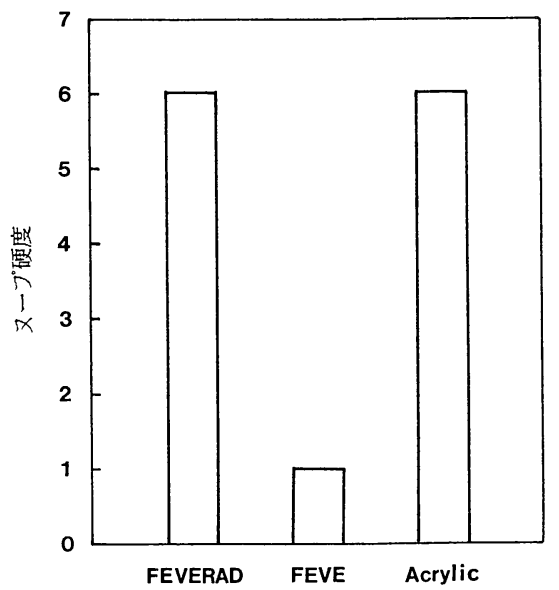

図15 硬化塗膜の表面硬度比較

試料：ポリイソシアナート架橋剤による硬化 フィルム(図13に同じ)
破断抗張力と伸び率を, FEVE，アクリルポリマ 一から得られた硬化塗膜の值と比較した。

この実験に用いた FEVE 硬化塗膜はよく伸び るが破断抗張力の小さいものであった。これを図 中のアクリルポリマー硬化塗膜と同程度の破断抗 張力とするために，FEVERADの設計を行った 例であるが，粒子のアクリルポリマー $T_{g}$ を $52^{\circ} \mathrm{C}$, アクリルポリマー粒子含有量 $60 \mathrm{wt} . \%$ とすること で, 破断抗張力, 伸び率ともアクリルポリマー硬 化塗膜の值を上回るものが得られた，同時に表面 硬度も大幅に向上させることができた（図 15）.

この FEVERAD 硬化塗膜の引張試験による破 断箇所の TEM 写真を図16に示す。アクリルポリ マ一粒子の変形が観察されるが，このような変形 による外部からのエネルギー吸収も機械的特性向 上に一役かっているものと考えている.

\section{2 紫外線透過率の制御}

通常 FEVERAD は, 粒径及び, 連続相と分散 相の屈折率差を調節することにより透明性を制御 している. 図17はFEVE 乾燥フィルムの透明性 一目視及び $500 \mathrm{~nm}$ 可視光線透過率 $(90 \%$ 以上か以 下か)で判定一に及ぼす，FEVERADの平均粒子 径と分散安定剂である FEVEと粒子アクリルポ リマーの屈折率差の影響を図示したものである.

一般に透明フィルムを得るためには, 平均粒子 径は $0.3 \mu \mathrm{m}$ 以下，屈折率差は 0.03 以下となるよ

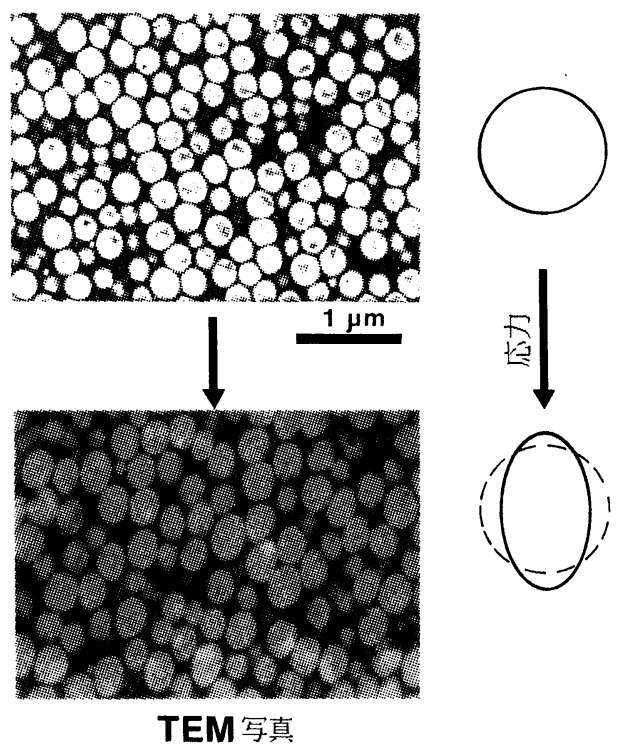

図16 引張り試験，破断箇所の TEM 写真 


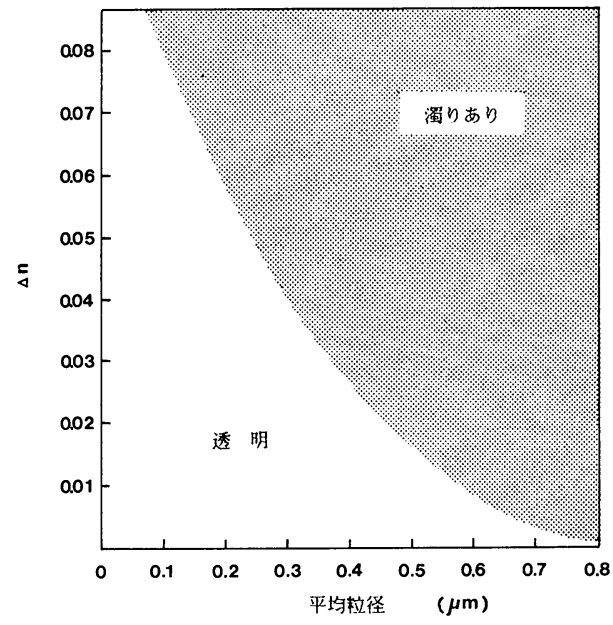

図17 FEVERAD フィムの透明性と平均粒子径, 粒子-連続相屈折率差の関係

試料フィルムの膜厚 : $50 \pm 5 \mu \mathrm{m}$

$\Delta n:$ 分散粒子ポリマーの屈折率-FEVEの屈 折率

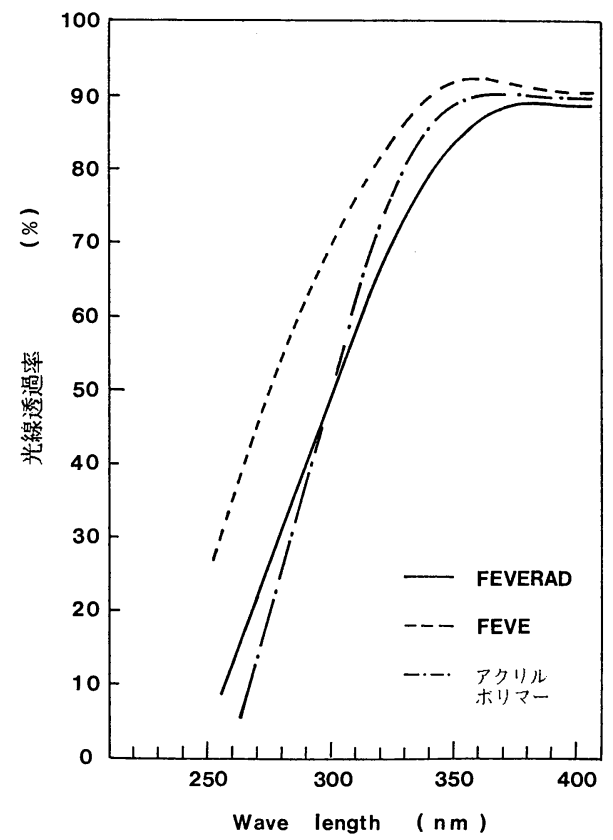

図18 硬化塗膜の紫外線透過率

試料：ポリイソシアナート架橋剤による硬化 フィルム(図13に同じ)

ら設計している.

一方，図18より紫外領域の光線に対しては FEVEフィルム $(50 \mu \mathrm{m}$ 厚 $)$ は, $300 \mathrm{~nm}$ の光線の

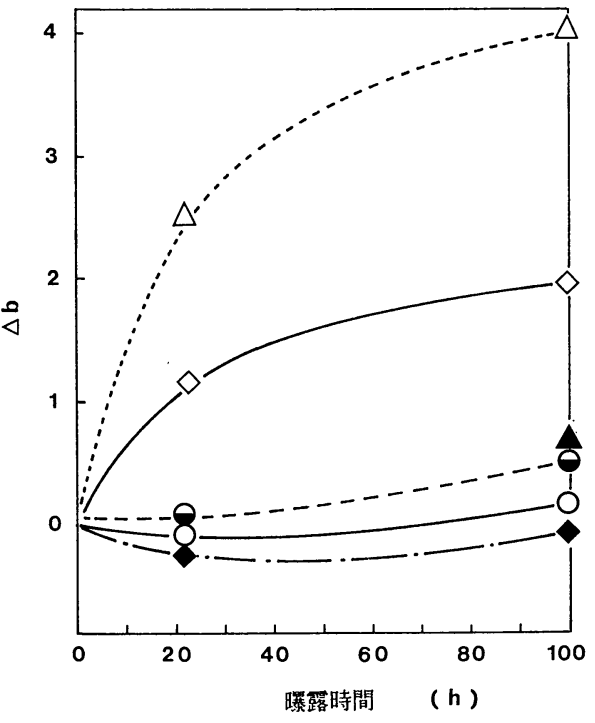

図19 FEVERAD フィルムが素地を保護する効果 $\Delta b:$ 黄変の尺度 $(\mathrm{SM}$ カラーコンピュータ(ス ガ試験機(侏)にて測定)

試料：ポリイソシアナート架橋剤による硬化 フィルム, 膜厚 $50 \mu \mathrm{m}$

$\triangle:$ クリヤーュートなし, $\diamond:$ FEVE,

ブレンド系(アクリルポリマー $=50 \mathrm{wt} \%)$,

: FEVERAD(分散粒子含有量 $=25$ wt \%)， $\bigcirc:$ FEVERAD (分散粒子含有量 $=50 \mathrm{wt} \%),($ アクリルポリマー

70\%程度を透過させるが，FEVERADフィルム (50 $\mu \mathrm{m}$ 厚)では同じ厚さのアクリルポリマーフィ ルム並の50\%程度しか通さないことがわかる。

これを実用的見地から評価した結果を図19に示 す.ニトロセルロース/アクリル系塗料(白エナメ ル）は紫外線にさらされることにより黄変しやす いそそのものの塗膜は殺菌灯照射 100 時間で $\Delta b=4$ 程度の黄変を示す. これに膜厚 $50 \mu \mathrm{m}$ とな るように各種透明塗料を塗装し同一条件で殺菌灯 照射を行った. FEVE 単独では $\Delta b$ は半分程度と なるものの確実に黄変した。一方 FEVERAD で は，アクリル粒子分が50 wt.\%の場合，アクリル ポリマー単独系同様 $\Delta b \doteqdot 0$ であり殆んど黄変が 認められなかった。ちなみに FEVERAD とアク リルポリマー含有量を同一にした FEVE/アクリ ルポリマーブレンド系では $\Delta b$ は 1 近くなり黄変 が認められた。アクリルポリマーが粒子として存 在することが，紫外線の透過を一層抑制し，素地 を保護する効果を発揮している20), 34). 


\section{3 耐污染性の向上}

耐污染性の評価については，污染の原因となる 物質, 気象条件, 污染の受け方一流雨水によるも のか，或は軒下の污れか etc.一等により結果が大 きく左右される場合がある。図20は，図21のよう な促進污染試験機を用いて，FEVERAD と FEVE 各硬化塗膜の污染性を比較したものであ る.エロージョン処理とは, 污染物質(カーボン,

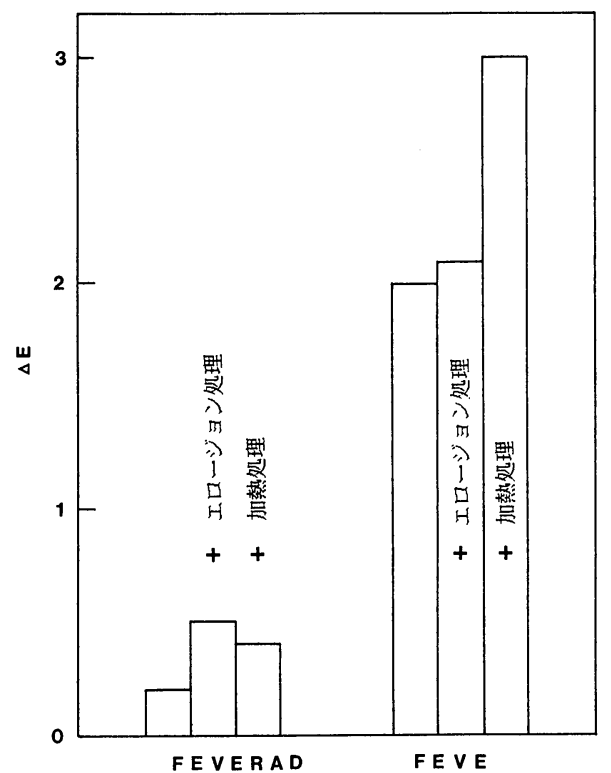

図20 塗膜表面污染性の比較

污染物質：カーボン，クレイ、コットン 試料：ポリイソシアナート架橋剤による硬化 フィルム(図13に同じ)

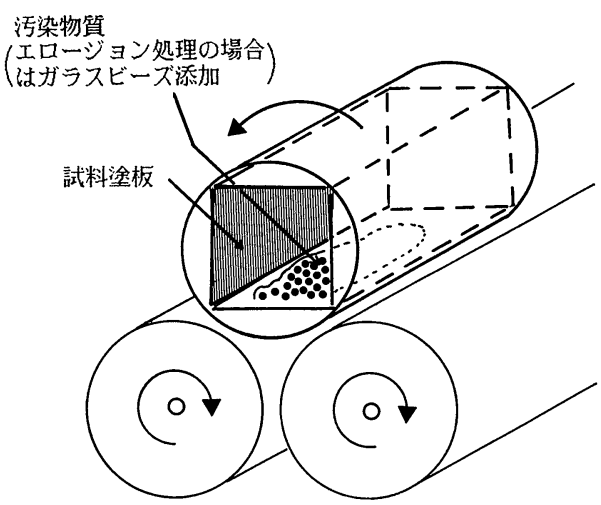

図21 促進污染試験機

試験片は污染物質とともに密閉された筒内に セットされ，一定時間回転運動を受ける。
粘土，木綿繊維系)にガラスビーズを加えたもの であり加熱処理とは促進污染試験後, 試験片を $70^{\circ} \mathrm{C}$ で 1 時間熱処理した後，污染物質をエアブ ローで除き色差 $\Delta E$ を測定したものである．いず れの条件でも FEVEよりも FEVERADのほうが 污染されにくいことを示している。この傾向は東 京都太田区南六郷における 1 年間の実際曝露試験 の結果ともよく一致している. 静電気の帯電性(表 3), 表面硬度(図15)等の影響が考えられるが更に 原因究明中である。

\section{4 塗装作業性の向上}

表 4 亿 FEVERAD, FEVE 各塗料の粘度特性を 示す．市場では，FEVERAD 塗料(建築上塗り用 として“アレスフロン・シリーズ”として上市) は，口ーラー，八ケによる塗装作業性が良く，塗 装後タレ難いといら評価を受けている。 FEVERAD 塗料では，降伏応力がより大きくタ レ難いことを表わしており，残留粘度がより低い ことはローラー, 八ヶの塗装時の軽さを表わして

\begin{tabular}{l|r|r}
\multicolumn{3}{c}{ 表 4 粘度特性 } \\
\hline & 降伏応力 & 残留粘度 \\
\hline FEVERAD 塗料 & 39 dyne $/ \mathrm{cm}^{2}$ & 6 poise \\
FEVE 塗料 & 9 dyne $/ \mathrm{cm}^{2}$ & 33 poise \\
\hline
\end{tabular}

Cone \& Plate 型粘土計 (30 rpm, sweeptime 30 秒)

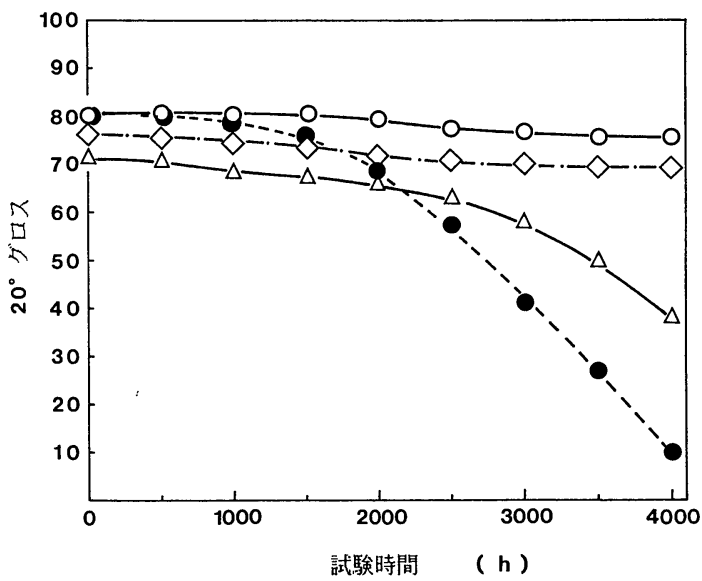

図22 促進耐候性試験結果

試料：ポリイソシアナート架橋剤による硬化 フィルム(図13に同じ)

$\bigcirc:$ FEVERAD, $\diamond:$ FEVE, $\triangle:$ FEVE $/ 乃$ クリルポリマーブレンド系 $(50 / 50), \bigcirc ： ア$ クリルポリマー 


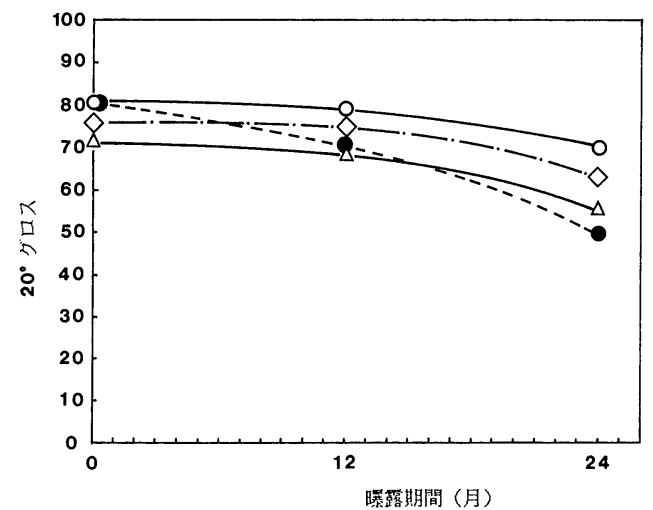

図23 屋外耐侯性試験結果 (沖縄)

試料は, 図22に同じ

いるといえる。

このよらに NAD 型とすることで粘度特性調節 の幅が広くなり，より広い用途に展開可能となる.

\section{5. まとめ}

以上, FEVERADの特性，実用的な優位性の 一端を紹介した。もちろん, 図22, 図23に示すよ らに，FEVE本来の耐候性は維持しており，更に 酸性雨に対する抵抗性も FEVEの高いレベルを 維持していることが確認されている.

今後は，高性能だけではなく高度な機能を発揮 するよらな FEVERADの開発へ進みたいと考え ている.

本稿が関連業務，研究に携わる方々にとって参 考になれば幸いである。

\section{引用文 献}

1) Sasaki, Y., Numa, N., Hirata, N.: 3rd Chemical Congress of North America, the Division of Fluorine Chemistry Meeting (1988, 195th ACS)

2）奴間伸茂, 平田信人：1988年度色材研究発表会要 旨集, p. 78 (1988)

3) Numa, N., Hirata, N.: Proceedings of XXth Congress of FATIPEC (Fédération d'Association de Techniciens des Industries des Peintures, Vernis, Emaux et Encres d'Imprimerie de l'Europe Continentale), p. 473 (1990)
4）奴間伸茂，平田信人：高分子学会予稿集，39-11, 4184 (1990)

5）関西ペイント：特開昭62-25103

6）関西ペイント：U. S. Pat. 4, 732, 941

7) 関西ペイント：Brit. Pat. 2, 179, 047

8）関西ペイント：W. G. Pat. 3, 622, 566

9) K. E. J. Barett: "Dispersion Polymerization in Organic Media”, John Wiley \& Sons, London (1975)

10）柴田 穔：高分子加工, 21, 331（1972）

11）村田耕一郎：最新工業塗装技術, 幸書房(1977) p. 136

12） ICI: 特公昭 40-7047, 40-19186, 43-23350他

13）Rohm \& Haas: 特公昭 36-10488, 38-16760他

14) Du Pont: U. S. Pat. 3, 405, 087 他

15) BASF: U. S. Pat. 3, 551, 525他

16) Celanese Coating:特開昭46-5237他

17) Cook Paint and Varnish: U. S. Pat. 3, 365, 414他

18） Ford Motors:特公昭 47-8537, 47-11838他

19）関西ペイント：特公昭 57-46445他

20）薮田元志：色材協会誌，63［4］209（1990）

21）柴田輝一, 河村允文: 塗料の研究, No. 118, Sept. p. 17 (1990)

22) Yamabe, M.: Proceedings of 9th International Conference in Organic Coatings Science and Technology, p. 357 (1983)

23) Kojima, G.: Proceedings of 11th International Conference in Organic Coatings Science and Technology, p. 113 (1985)

24) Munekata, S.: Progress in Organic Coatings, 16 p. 113 (1988)

25）旭硝子：特開昭 57-34107他

26）大日本インキ化学工業: 特開昭 59-102962

27） セントラル硝子：特開昭 61-57609他

28）三井石油化学工業：特開昭 61-141713他

29）日本メクトロン：特開昭 63-213508他

30）奴間伸茂(共著)：アクリル樹脂の合成・設計と新 用途開発, 中部経営開発センター出版部 (1985), p. 82

31）奴間伸茂：色材協会誌「フッ素ポリマーを分散安 定剂とする非水ポリマーディスパージョンのモルホ ロジー」(投稿中)

32) Numa, N., Murata, K., Sasaki, Y.,: Eleventh International Conference in Organic Coatings Science and Technology, Volume 9-Advances in Organic Coatings Science and Technology Series, Technomic Publishing Company Inc. (1987) p. 85

33) Yabuta, M., Sasaki, Y.: Organic Coatings, Science and Technology, 8, Marcel Dekker Inc. (1986) p. 329

34）薮田元志：1988年度色材研究発表会要旨集, p. 62, p. 124 (1988) 